\title{
Saviour Siblings - Current Overview, Dilemmas and Possible Solutions?
}

\author{
SANDRA O. SAMARDŽIĆ
}

\begin{abstract}
In certain cases, when an already born child is affected with a fatal disease and needs transplantation, the only possible solution could be the creation of saviour sibling. Saviour sibling is a term that refers to a child born through a procedure in which an embryo, created in vitro, is being tested in order to determine whether such an embryo could provide stem cells or tissue for an already born, ill child. If the embryo is both, a matching donor and free of the disease, it could be implanted and after the birth of a child, the umbilical cord stem cells or tissue could be used for treatment of a sick sibling. However, this procedure poses a number of dilemmas. This paper aims to give a brief analysis of these issues, to address some of the main concerns and to provide possible solutions for future regulation of this technique.
\end{abstract}

Keywords: - Saviour Sibling - Right of the Child to Health - Medically Assisted Reproduction • Bone Marrow • Stem Cells •

CORRESPONDENCE ADDRESS: Sandra O. Samardžić, University of Novi Sad, Faculty of Law, Novi Sad, Serbia, e-mail: sandra.samardzic@pf.uns.ac.rs. 
The progress of science is unstoppable and by nature it is positive with a clear goal: to make human life easier (Zergollern, 1980: 15). The practical application of science is something quite different and it cannot be examined separately from its impacts on humans.

One of the major scientific discoveries, in the field of medically assisted reproduction (hereinafter: MAR), is the possibility to test embryos in vitro. Preimplantation genetic diagnosis (hereinafter: PGD) is a procedure which involves in vitro testing of embryos where, based on the obtained data, only the embryos that have desirable genetic features are used or implanted. ${ }^{1}$ This procedure may be used for both medical and non-medical purposes (Robertson, 2003: 214). Regarding medical purposes, PGD may be used for testing in order to discover the presence of some genetic diseases as well as to determine the existence of diseases that may develop later in life. ${ }^{2}$ A special type of PGD used for medical purposes has the aim of improving the health of an existing sibling suffering from a fatal disease. In this situation, PGD represents an option for parents who have a child with a condition that requires a bone marrow or stem cell donation when neither the parents nor anyone else in the family is a matching donor. Using the PGD technique, parents can select embryos that would be perfect donors for their existing, sick child. It is precisely this procedure that will be the focus of this paper.

The second group of testing, that uses PGD for non-medical purposes, involves embryo testing in order to determine a baby's gender, eye and hair color, etc.

\footnotetext{
${ }^{1}$ Unlike this procedure, prenatal diagnosis is a procedure conducted during pregnancy. Based on the results obtained from the testing a decision is made on possible termination of pregnancy in case it has been determined that a fetus has unwanted genetic traits, i.e. the child would be born with some sort of anomalies.

${ }^{2}$ Diseases such as Alzheimer's disease and Huntington's disease that may not manifest themselves in childhood but result in significant health issues in $30 \mathrm{~s}$ and $40 \mathrm{~s}$.
} 


\section{Medicine, LAW \& Society \\ S. O. Samardžić: \\ Saviour Siblings - Current Overview, Dilemmas and Possible Solutions?}

Saviour Siblings - Phenomenon

"Saviour sibling" 3 or "medicine baby"4 are terms that describe children that are born through a procedure in which embryos, created in vitro, are tested by using a special technique of tissue typing in conjunction with PGD. In this way, it is possible to determine whether such embryos could provide umbilical cord stem cells or tissue for an already born child that is affected with a fatal disease and needs transplantation. For transplantation to be carried out, both a donor and a recipient must have matching tissue types (genetic component of Human Leucocyte Antigen (HLA)). This is necessary in order for a recipient's immune system to accept the donor material and not recognise it as a foreign material and thus reject it. ${ }^{5}$ Even though different types of transplantation exist, such as organ, tissue, and blood transplantation, as well as stem cell transplantation, the procedure of using PGD in order for saviour sibling to be born, deals only with the transplantation of stem cells obtained from the umbilical cord and bone marrow transplantation. Performing this procedure in cases where organ transplantation is required is not permitted in most jurisdictions. ${ }^{6}$ In addition to testing these embryos for HLA compatibility with an affected, currently ill child, they also have to be free of the disease.

The first case involving a savior sibling baby occurred in the USA in 2000. A baby boy, Adam Nash, was the first baby born as an adequate donor for his sister, Molly, who suffered from a rare form of anemia. The Nash family saw the birth of Adam, whose blood from the umbilical cord was used for treating his sister, as an unrealistic victory in

\footnotetext{
${ }^{3}$ In foreign writing a common term is "saviour sibling" that was first used by authors Spriggs and Savulescu in 2002 (Spriggs \& Savulescu, 2002: 289).

${ }^{4}$ The term medicine baby was first used in the French media in 2011 when the first baby was born using this method.

${ }^{5}$ Council of Europe (2015), Background document on preimplantation and prenatal genetic testing, (hereinafter: Background document).

${ }^{6}$ There are real life cases of organ donation between brothers and sisters that are minors. One of the most famous is the case of Hart v. Brown from 1972 involving a little girl Kathleen that required a kidney transplant. Her parents wanted to save her live by transplanting a kidney from her twin sister Margaret. However, although parents were ready for such a procedure, the hospital refused to perform the surgery before obtaining a permission from the court. The Supreme Court of Connecticut took the position that parents may give consent to organ donation of their children. A method of weighing all the relevant circumstances in this case, become known as the Hart test. There is another parallel test, known as the benefit test according to which the court needs to assess what are the benefits of organ donation for the donor, which is very difficult to do. On the contrary, the Hart test takes into consideration the position of the donor as well as a person requiring such donation. So in the case of Hart v. Brown the court determined that taking a kidney from Margaret would have mild effects on her in comparison to Kathleen, for whom the surgery was crucial, therefore the final conclusion of the court was that it would be unjust to prohibit such procedure (Allensworth, 1972: 244-248); However, what caused concern was a lack of any regulation, or standards, that would be widely accepted in the society and that could be used to determine the child's best interest (Freeman, 1983: 256).
} 
a battle that seemed almost lost. ${ }^{7}$ However, it seems that no procedure in the field of MAR caused such great moral and ethical dilemmas as this one. Analyzing the moral aspects of the procedure, Wilkinson states that when compared with any other form of selective reproduction, the birth of a child intended to be used as a donor to his/her older sibling, from the very start entails enormous moral dilemmas (Wilkinson, 2010: 109). If the procedure is not successful (or is not permitted), a child that needs this type of assistance will surely die (Wilkinson, 2010: 109). On the other hand, some authors see this procedure as a form of selective reproduction and raise concerns about the remaining embryos that were not chosen and thus not implanted (Hudson, 2002).

The uniqueness of this procedure lies in the fact that the life of a child can be saved when there is no alternative treatment. This procedure, however, requires an assessment of the best interest of not one, but two children. On the one hand, we have a child that requires assistance and whose health, and perhaps very life, depends on whether a compatible donor will appear, while on the other hand, we have a child, or an idea of a future child, whose role as a donor is determined even before he or she was conceived, or born. It is clear that this procedure presents a very complex sub-field of MAR, which similarly to surrogacy, impacts not only the most intimate personal and family relationships, but also the sovereignty of national legal systems (Kraljić, 2015: 82). Even though some authors claim that the interest of the family should not be the predominant concern (Gavaghan, 2015: 931), others point out that the benefit to the family is less speculative than the potential interest of the future child (Taylor-Sands, 2015: 933).

\section{Comparative Review}

In an attempt to find the right approach about saviour siblings and to the question, whether this procedure should be regulated and how, it is helpful to briefly analyze the positions other Member States have adopted.

As far as the European Union is concerned, nine countries allow this procedure. ${ }^{8}$ Of course, even these countries set certain limitations and requirements for when the procedure may be used, as explained below. For example, Norway forbids PGD for HLAtyping alone. This procedure is allowed only when there both is a risk of transmitting a hereditary disease to a child and the disease of the sibling can be successfully treated by bone marrow transplantation (Background document, 2015: 30). On the other hand,

\footnotetext{
${ }^{7}$ Today, Molly is 25 and tries to live normal life. See more about this case: (Hendrickson, 2017).

${ }^{8}$ Belgium, Denmark, France, Greece, Norway, Portugal, Spain, Sweden, UK. (Background document).
} 


\section{MEDICINE, LAW \& SOCIETY \\ S. O. Samardžić:}

Saviour Siblings - Current Overview, Dilemmas and Possible Solutions?

Belgium allows this technique for the therapeutic interest of an already born child of the prospective parents. In this case, the fertility centre must assess whether or not the desire of parents to have a child serves solely for the therapeutic interest. ${ }^{9}$ Spain regulates the issue of saviour siblings in an article ${ }^{10}$ that deals with PGD. It is stated that the application of PGD for the therapeutic purposes for the third parties requires special authorization on a case-by-case basis. Namely, the corresponding health authority, after a favourable report from the National Commission of Assisted Human Reproduction is presented, must evaluate the clinical, therapeutic and social characteristics of each case. A similar solution can be found in the Portuguese law. In Portugal, the application of PGD techniques that have a recognized scientific value in diagnosing, treating or preventing serious genetic diseases is permitted after the consideration of the National Council for Medically Assisted Procreation. ${ }^{11}$ Sweden allows this technique but only in exceptional cases. In Sweden, the permission of the National Board of Health and Welfare is necessary and it can be given only if there are exceptional grounds for allowing such use. ${ }^{12}$ In the Greek ${ }_{\text {law }}{ }^{13}$, a special article, separated from the one that refers to PGD, regulates a research which is aimed at achieving pregnancy. It is stated that the research may be carried out on human gametes, zygotes and fertilized ova, where the purpose of the research is to acquire important knowledge relevant to the successful implantation. The authorization of a special authority is needed and, among other things, the benefits expected from the research must outweigh the risks to the child being born. As for the preimplantation genetic diagnosis (PGD) in Denmark, the Law No. 240 of April 5, 2004, amended the Section 7 of the Law 460/1997, states that the National Board of Health can permit the use of PGD as part of the artificial fertilization in certain cases. ${ }^{14}$ Such cases are related to the treatment of children with potential deadly diseases. According to these amendments, PGD is now allowed along with tissue typing when there is a need for the treatment of a child with a life-threatening disease. Guidelines from April 2004 set more precise requirements for circumstances in which this technique may be performed.

\footnotetext{
${ }^{9}$ Law of 6/7/07 concerning medically assisted procreation and the use of supernumerary embryo and gametes (Moniteur Belgique du 17/07/2007) - article 68.

${ }^{10}$ Spanish Law on Human Reproduction, LEY 14/2006, de 26 de mayo, sobre técnicas de reproducción humana asistida, Boletín Oficial del Estado Número: 126, 27/05/2006, Disposición n. 9292, Páginas: 19947-19956 article 12 .

${ }^{11}$ Portuguese Law no. 32/2006 of the Parliament, Lei n. 32/2006. de 26 de Julho. Procriação medicamente assistida - article 28 .

${ }^{12}$ Swedish Genetic Integrity Act (2006:351) - Chapter 4, Section 2.

13 Greek Law No. 3305 (Government Gazette A17 27.1.2005), Applying Medical Assisted Reproduction.

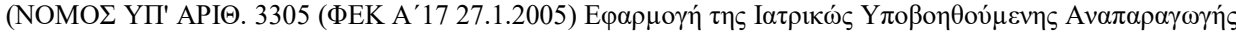
- article 12.

14 Norwegian Law Ot. prp. nr. 26 (2006-2007), Om lov om endringer i bioteknologiloven (preimplantasjonsdiagnostikk og forskning på overtallige befruktede egg), - 4.4.2
} 
Among other things, these guidelines permit PGD in instances where the purpose is to help a child of one or both of the parents. In addition, PGD is allowed if the existing sick child is affected by a life-threatening disease. Furthermore, to be permitted, there must be a reasonable medical expectation that this treatment would lead to a decisive improvement in the child's state of health or survival. Finally, the child that will be born must not be subjected to interventions which may be regarded as potentially welfare threatening, severely painful or otherwise offensive. ${ }^{15}$

The regulation on PGD in the UK was strongly influenced by the cases of the Hashimi and Whitaker families. Four children were born to the Hashimi family. The youngest child, Zain, was born with a blood disorder known as Thalassemia major. ${ }^{16}$ Zain's condition could have been treated only with the stem cells from a compatible donor. Mrs. Hashimi decided to give birth to another child since the existing brothers and sisters could not be donors to little Zain. The chances of giving birth to a child that would be an adequate donor was only one in four. Furthermore, the chances that a child would be an adequate donor and at the same time free of disease, were far slimmer. One pregnancy was terminated as it was discovered that the fetus carried the same disease. The other pregnancy resulted in the birth of a healthy boy who unfortunately was not a compatible donor. After that, Mr. and Mrs. Hashimi managed to obtain 15 embryos through IVF in a clinic that had been granted permission from the HFEA for such a procedure. However, only one of the embryos could be used as a compatible donor. Unfortunately, this embryo was carrying the disease itself. In another procedure, two embryos were found to be free from the dangerous disease and suitable to serve as donors to Zain. One of the embryos was implanted but did not result in pregnancy.

In the second case, a little boy named Charlie Whitaker was suffering from a rare form of anemia. This form of anemia can be hereditary but it can also be the result of genetic mutations, as it was the case with this boy, since it was determined that his parents did not have this gene. As in the previous case, a stem cell transplantation was needed to treat Charlie. Since his sister could not be an adequate donor, the parents decided to seek permission from the HFEA, through a clinic in London. However, their request was denied. As had also been stated in the response of the HFEA in the Hashimi case, since

\footnotetext{
15 Ibid.

${ }^{16}$ This is the most severe form of this disease. The relevance of PGD in such cases is evidenced from data that in Serbia, in families that have genetic predisposition to this disease, not a single child was reported with the most severe form of Thalassemia - Thalassemia major, since genetic counseling was introduced for Thalassemia and prenatal diagnosis (Evropski dan retkih bolesti, 28.2.2011, http://www.rts.rs/page/stories/sr/story/125/Dru\%C5\%A1tvo/850604, 25.5.2019).
} 


\section{MEdicine, LAW \& SOCIETY \\ S. O. Samardžić: \\ Saviour Siblings - Current Overview, Dilemmas and Possible Solutions?}

the disease in question was a hereditary genetic condition, the use of a PGD procedure would have been beneficial for the future child because at the same time it would prevent the disease from being transmitted to a new offspring. On the other hand, unlike in the case of Hashimi, Charlie's disease was not hereditary; it was the result of random spontaneous gene mutation. This means that the chances of Mr. and Mrs. Whitaker having another child with the same form of anemia, were slim. Therefore, the possible benefit from PGD was negligible.

Mr. and Mrs. Whitaker sought help from a clinic in the USA. The clinic conducted tests and determined that embryos would be adequate donors and accordingly they were implemented. In June 2003, a baby boy James was born and cells from his umbilical cord were used for treating Charlie. In October 2004, Dr. Ajay Vora confirmed that Charlie was in remission but that his condition required further follow-ups.

Not long after these two cases, in 2001, the UK Ethics Committee of the Human Fertilisation and Embryology Authority, stated that "this technique should also be made available in cases when a child is suffering from a life-threatening disease, even when such a disease is not hereditary". ${ }^{17}$

This means that in the UK it is now possible to perform PGD with HLA typing even in cases of non-hereditary diseases. The paragraph 1ZA (1)(d) of the UK Law on Human Fertilization and Embryology states that a licence for embryo testing can be granted only for a limited scope of purposes. One of them is a "case where a person ("the sibling") who is the child of the persons whose gametes are used to bring about the creation of the embryo (or of either of those persons) suffers from a serious medical condition which could be treated by umbilical cord blood stem cells, bone marrow or other tissue of any resulting child, establishing whether the tissue of any resulting child would be compatible with that of the sibling". Paragraph $1 \mathrm{ZA}(4)$ states that the "other tissue" referred to in the paragraph $1 \mathrm{ZA}(1)(\mathrm{d})$ does not refer to the whole organ. This provision ensures that embryo testing is not allowed in situations where the older child is in the need of an organ.

\footnotetext{
${ }^{17}$ Ethics Committee of the Human Fertilisation and Embryology Authority, Ethical issues in the creation and selection of preimplantation embryos to produce tissue donors, London, 2001 Nov 22, section 3.14. http://hfeaarchive.uksouth.cloudapp.azure.com/www.hfea.gov.uk/docs/ELC_5_july03.pdf, 23.12.2017.
} 
The answer as to whether this procedure is allowed in Serbia is unsettled. Firstly, the Law on Bio-Medically Assisted Fertilisation ${ }^{18}$ (hereinafter: LBMAF) in Article 25, among other things, prescribes that biomedically assisted fertilization (hereinafter: BMAF) may be provided only to "a woman and a man that require assistance through biomedically assisted fertilization in treatment of their infertility". Furthermore, Article 47 of the same law regulates PGD and states that in "biomedically assisted fertilization the preimplantation genetic diagnosis is permitted exclusively if there is a risk of transmitting a hereditary disease, to help diagnose genetic disorders and chromosomal abnormalities, or if that is necessary in cases of repeated failed biomedically assisted fertilization". From these two articles, it could be concluded that PGD is only allowed as part of BMAF and only to the couples requiring assistance in the treatment of their infertility. In other words, couples that do not have difficulty conceiving but nevertheless face the possibility of hereditary disease transmission and want to prevent this disease from being transmitted to their future offspring, are not allowed to use PGD. Even though this conclusion could be the result of literalism, it seems that the original legislative intent was to allow PGD to all the couples with a family history of certain diseases, regardless of their fertility. This is the only logical interpretation confirmed by the Law on Prevention and Diagnosis of Genetic Diseases, Genetically Conditioned Anomaly and Rare Diseases. ${ }^{19}$ Furthermore, the LBMAF strictly regulates that PGD is allowed "if there is a risk of transmitting a hereditary disease, for diagnosing a chromosome or genetic disease, or if that is necessary in the cases of a repeated BMAF procedure failure". The law states nothing about HLA typing, i.e. about saviour siblings, and a straightforward conclusion that such a procedure is not allowed would be questionable at the very least. Let us consider, for instance, a hypothetical case in which a couple that has a child with a hereditary disease needs stem cells transplantation but where there is no compatibility within the family. It is possible for this couple to undergo PGD in order to prevent the very same disease being transmitted to their future child. However, the question is whether a doctor can reveal the fact that some tested embryos are both free of the disease and compatible donors to the existing child.

\footnotetext{
${ }^{18}$ Law on Bio-medically Assisted Fertilisation, Official Journal of Republic of Serbia, no. 40/2017 \& 113/2017 - other law.

${ }^{19}$ This law regulates predictive, prenatal, postnatal and target diagnostics in children and adults. Article 26 that refers to prenatal diagnostic prescribes that the provision of this Article shall also apply to methods of preimplantation genetic diagnostics in the procedures of biomedicine-assisted fertilization. In the very same article, it is stated that prenatal diagnosis is undertaken for the purpose of getting healthy and desired offspring and for that cause determination or exclusion of a particular genetic disease, genetically conditioned anomalies or rare diseases in embryos or foetuses are being performed.
} 
The law that regulates prenatal genetic diagnostics is strict regarding some other additional information that could be detected through testing. For example, if the gender of the embryo is identified during the prenatal diagnostics procedure, such information may be revealed to the pregnant woman only after the expiry of the tenth week of pregnancy. Given that the provision of this article should be applied in the case of PGD, the information concerning gender of the embryo tested in vitro is something that parents are not allowed to find out. However, having in mind moral, cultural and legal dilemmas that saviour sibling provokes, it should be wrong to carry out this procedure without strict legal permission.

Another interesting thing to mention is the Article 51 of the Law on Transplantation of Cells and Tissue of the Republic of Serbia ${ }^{20}$, which regulates the question of who can be a donor. According to this article, a donor of cells, or tissues, may be a person above the age of 18 , if he or she has a full legal capacity, i.e. that he or she is capable of making sound judgments and decisions. As an exception, collecting and storing blood-generating cells from minors is permissible provided that the cells are separated from the umbilical cord of a baby born alive that may be used for transplantation or used for relatives and non-relative family members of the baby born alive. From this provision, we can deduce that the law allows collecting stem cells from the umbilical cord for medical treatment of relatives and non-relatives alike. On the other hand, testing and choosing embryos that are determined to be free of disease and a matched donor to his/her sick sibling is not permitted

A possible solution for a child that is in need of a stem cell treatment is to try to find a suitable donor among the family members or through the bone marrow registry of potential donors. Another possibility, not yet realized however, could be through the cell and tissue bank. The Law on Transplantation of Cells and Tissue of the Republic of Serbia prescribes this possibility. According to this regulation, this bank would store stem cells from the umbilical cord harvested at the birth of every baby. Even though this could be very helpful, such banks have yet to be established. Finally, there is always a possibility of traveling abroad to the countries which allow the creation of saviour siblings.

\footnotetext{
${ }^{20}$ Law on Transplantation of Cells and Tissue, Official Journal of RS, no 72/2009.
} 


\section{Certain Dilemmas Concerning Saviour Siblings}

Prohibiting saviour siblings would mean denying the possibility of treatment to an already born, seriously ill child. Most likely, this prohibition would consequently deprive him/her of the right to life. However, while allowing this procedure could be of help to a child requiring donation, it would certainly raise questions about endangering the health and interests of a child that is to be born as a donor.

Several objections, which could be grouped in three, are raised when dealing with an issue of saviour siblings.

- First of all, those that object to this technique believe that this procedure treats children as a means to achieve something rather than an end in itself.

- Furthermore, there is a fear that allowing this technique will lead to "designing" babies.

- Finally, there is a fear that this technique puts a child's psychological and physical health at risk.

The opponents of this procedure have primarily argued that it objectifies the child by turning it into a mere tool, and as such contradicts the basic ethical principle that society should never use human beings merely as a means to an end, however admirable that end may be (King, 2003). From this standpoint, the PGD procedure is morally wrong because it does not abide by the stated principle, even in a situation when such a procedure brings no harm to the yet unborn child. In that sense, Gavaghan considers that, even if all the persons involved benefit to some extent, PGD nevertheless may not be considered as ethically acceptable, because some of the persons involved would be treated as a mere tool (Gavaghan, 2007: 57).

However, there are several counterarguments to the above-mentioned objection. First of all, the fact that parents want to have a child who would be an adequate donor speaks nothing about their desire to have that child for other (non-medical) purposes. It is entirely possible that they desire to have an offspring, and in that case, society certainly should not consider the child merely as a tool. In that situation, the child is the goal in and of itself. Love that parents will have for that child cannot be questioned, because love cannot be measured even when a child is conceived naturally, without the idea of that child serving as a donor. In addition, a definite answer can never be given as to whether the parents, even when conceiving a child naturally, are always guided by the reasons that 
exclude viewing a child as a means to an end. Parents may see in their child or children a possibility to improve their family business, or maybe they want to ensure for themselves someone that would help them when they get old. Whatever the reasons, how they treat their child after that child is born is far more important than what the motives were when conceiving it (Taylor Sands, 2013: 145). Also, the fact that parents are prepared to have another child in order to cure the one that they already have, indicates that they are very much dedicated to the welfare of their children and that they will love and nurture any additional children (Robertson, 2002: 34-40).

Furthermore, the main concern in relation to this procedure should be the question whether a child born as a result will in any manner, and at any time, be put in danger. ${ }^{21}$ In this regard, we must consider the potential adverse health consequences the future child might face since the right to a healthy life is one of the fundamental children's rights under EU law.

First, we must consider the possible impact of the procedure on both the child's mental and physical health. A possible impact on the physical health of a child is limited to taking blood or bone marrow, provided that harvesting stem cells from the umbilical cord, which poses no risk, was not successful. As for the PGD procedure and the embryo testing procedure, carried out in order to determine whether they may be potential donors, not a single study has been conducted so far on the long-term effects that this procedure may have on the health of children. Since the testing consists of removing one or more cells from the embryo, it is possible to inflict damage to the embryo itself. ${ }^{22}$ However, these children are at no greater risk than children that were subjected to the PGD procedure in order to prevent transmitting a certain disease. Having in mind that embryo testing for the purpose of preventing disease transmission is widely accepted and does not cause greater opposition, we do not see why the same procedure, used for achieving a different goal, would be wrong. As one mother, that was seeking permission for this procedure in order to save her already born child, said: "nowhere else are parents' motivations put under a microscope prior to conception - for example, a child conceived to inherit the family business or continue the family name" (Spriggs \& Savulescu, 2002: 289). Finally, as another parent said: "We are not seeking to custom-design a baby, we just want

\footnotetext{
${ }^{21}$ Science and Technology Committee, Human Reproductive Technologies and the Law: Fifth Report of Session 2004-05, Vol. 1, §125, https://publications.parliament.uk/pa/cm200405/cmselect/cmsctech/7/7i.pdf, 5.3.2019.

${ }^{22}$ In support of this view is a study done on mice that were subjected to PGD procedure in embryonic phase which revealed that the mice experienced excess weight and memory problems later in life; (Yang Yu et al., 2009: 1490-1500).
} 


$100 \quad \begin{aligned} & \text { MEdiCINE, LAW \& SOCIETY } \\ & \text { S. O. Samardžić: } \\ & \text { Saviour Siblings - Current Overview, Dilemmas and Possible Solutions? }\end{aligned}$

permission to pick the one embryo that does not have the disease and is a compatible tissue match" (Spriggs \& Savulescu, 2002: 289).

The authors Sheldon and Wilkinson provide a good rebuttal to the assertion that the PGD procedure when utilized to prevent a hereditary disease transmission is considerably different, because in that case, the PGD procedure prevents transmission of a hereditary disease, and therefore the benefit gained by a child far outweighs the risk entailed in the procedure. Namely, these two authors claim that it is erroneous to presume that PGD prevents the transmission of certain diseases. Rather, this procedure only serves the purpose of determining whether the embryos are healthy from the moment of their creation but does not render treatment for the embryos. From that perspective, the PGD procedure is not much more different from a situation where it is performed in order to select compatible donors. In both cases, PGD determines which embryos may be used, that is, which embryos, without this procedure, would surely not be used (Sheldon \& Wilkinson, 2004: 535). If we adopt that position, both procedures have the same goal. Further, when we consider the possible benefits to be achieved, we may conclude they are the same for embryos examined in both procedures, because it breathes life into the selected embryos.

As for the possible impact of this procedure on the psychological health of a child that is being born to serve as a donor to a sick brother or sister, the fear is that the child would suffer from lack of self-confidence believing that parents had him or her only to help in providing treatment to older siblings. In that sense, it is possible, as was already mentioned, that the child may feel like a pawn, growing up believing he or she would not have been born had it not been for his or her sibling's disease.

It is highly questionable whether the possible impact on the child's psychological health is of greater importance than the life of another child that has already been born, or the life of the very child that is being born through this procedure. A parent that undergoes the necessary training and, later, through the adequate upbringing of the child in question, can either prevent or minimize the possible psychological impact, by advising the child of the truth in the right way. On the other side of the equation, there is a sick child who has no hope for a cure, and either a healthier life or even a life at all, in the absence of finding the right donor. There is no other way to improve this child's health as his illness is certain. Finally, can we really limit the reproductive autonomy of parents in such cases by claiming that it would be better to have "happier" children be born? (Sheldon $\& W i l k i n s o n, 2001: 97)$. If this is the approach that we take, there is always a better version 


\section{MEDICINE, LAW \& SOCIETY \\ S. O. Samardžić: \\ Saviour Siblings - Current Overview, Dilemmas and Possible Solutions?}

of ourselves that could have been born, but that may not justify the restrictive policy of the state in this domain (Sheldon \& Wilkinson, 2004: 537).

Author Harris points out that if we consider the welfare of a child as a principle of utmost importance, then of paramount concern should be ensuring the birth of the child, at least unless such birth would create greater burdens than benefits (Harris, 2000: 29). By comparing these cases with cases where PGD was used in order to give rise to the birth of a child of a specific gender, or for the purpose of having a child with a specific handicap, Taylor Sands points out that testing used for selecting an embryo that would grow up to be an adequate donor is a less controversial procedure, because it has therapeutic benefits for the sick child (Taylor Sands, 2013: 6). In addition, we must not underestimate the possible positive effects on the psychological health of a child that is being born as a result of this procedure. Namely, the knowledge that his or her birth saved the life of a sibling may indeed not only be empowering but also engender positive feelings and emotions that are the mirror opposite from those the opponents of this procedure espouse.

It does not follow that a child conceived primarily for the purpose of treating a sick sibling suffers a violation of the right to a healthy life, be it physical or psychological. However, the fact that such children do not actually suffer a violation of the right to health certainly does not imply that the law should presuppose that any child should undergo a medical procedure for the sole purpose of promoting a welfare of another child (Delany, 1993: 42). Taylor-Sands explains that a child's 'basic interests' has to prevail over 'collective interests' of family (Taylor-Sands, 2013: 52,72) and Jackson claims that we are here actually dealing with a duty to avoid 'significant harm', a standard that can justify state intervention in parental autonomy (Jackson, 2015: 929). ${ }^{23}$

\footnotetext{
${ }^{23}$ European Convention on Human Rights, in article 8, contains similar provision according to which there shall be no interference by a public authority with the exercise of the right to respect for his private and family life except such as is necessary ... for the protection of health or morals, or for the protection of the rights and freedoms of others. This article was of a special importance in cases concerning the issue of surrogacy as a one more issue of bioethics (Kraljić, 2015).
} 


\section{Things to Consider When Regulating the Issue of Saviour Siblings}

PGD is a procedure that has now been performed for more than twenty years and yet there are no detailed studies showing what possible adverse consequences the procedure can have on the future child. Additionally, the widespread acceptance of this technique as a method of preventing the birth of babies with certain anomalies is abundantly clear, since most of the countries today allow it and it causes no greater public opposition. Performing PGD in conjunction with HLA typing does not pose any greater risk than performing PGD alone. If the PGD procedure is safe enough to enable couples to have a child free of certain genetic conditions then it is safe enough to be used in other situations where its application will prove beneficial.

Furthermore, the process of cell and tissue donation does not lead to infringement of the child's right to health, because the child may only legally donate stem cells from the umbilical cord or from the bone marrow. Organ donations are absolutely forbidden. Concerning the possible impact on the psychological health of a child, we believe these fears are overblown and may be alleviated in various ways. In any event, such fears pale in comparison to the benefits gained by saving another's life.

However, when regulating this issue, several issues need to be addressed apart from prohibiting organ donation. First, it is necessary to define the circumstances under which this procedure should be allowed, or, more precisely, what medical conditions warrant saviour siblings being born. The legislator must also determine whether the procedure should be permitted not only in cases involving hereditary diseases but also for other diseases as well. Consequently, there is an issue regarding whether the procedure should be used for the previously specified conditions or simply on case-to-case basis. Then, there is another dilemma that causes a great controversy amongst authors. The question is whether the donation should be permitted only for siblings or whether it should be allowed for parents and other relatives as well. Finally, yet importantly, there are questions regarding which authority should be competent to make these decisions and how they are to be made. ${ }^{24}$

\footnotetext{
${ }^{24}$ At the same time, the question arises whether consent of both parents is needed, when the moment for transplantation comes. Namely, if parents split, does decision making rests with the parent that is acting as a guardian or to both parents. If we were to observe this hypothetical situation from the perspective of our legal system, we would arrive at the conclusion that consent of both parents would be required, because, in case of divorce, or termination of joint life between parents, the parent that is not exercising parental rights still has the right to decide on important issues concerning children, which includes decisions on major medical procedures; for more on the topic (Draškić, 2013: 38).
} 
Undoubtedly, it is very difficult to decide when this procedure is justified. Having in mind that prohibiting it may lead to fatal consequences, some authors believe that those that oppose it have the burden of establishing how the death of a child would be outweighed by the consequences of using PGD for these purposes (Sheldon \& Wilkinson, 2004: 533). Although in our judgment this procedure should be allowed even in cases that do not involve hereditary diseases, nevertheless, some limitations need are warranted. For example, before the decision is made to utilize the procedure, it is crucial to consider all of the possible options and alternative treatment methods. Additionally, it is equally important to determine whether in the absence of the procedure the particular disease would lead either to death or to a considerable diminishment of the diseased individual's capacities. Again, these are concededly difficult questions to answer as we venture into an area without clear boundaries. Still, it will be crucial for a competent, medical body, to examine and weigh all of aspects of the particular situation and not simply to permit this procedure at any cost.

As for the issue, or objection, that the scope of application of this procedure could be extended to the treatment of parents or other relatives, we contend that the fear is unjustified as stem cells from the umbilical cord may be used only for the treatment of small children. Bearing in mind the importance that each passing day has in successfully treating children, the competent institutions are sometimes requested to make the final decision on approval of the procedure, as urgently as possible in order to increase the success rate of the treatment (Duke, 2006: 355-356). In addition, in cases where donation would be necessary to adults, there is a different mechanism that could help in solving this issue, without the need to create special embryos for that purpose.

As for setting the parameters of who can benefit from the procedure, it would be possible to limit it only to siblings, because embryos may be created and tested for harvesting stem cells from the bone marrow which is a more invasive procedure.

Finally, there is a separate issue of what should constitute the competent authority for making decisions regarding the saviour siblings. We believe that ethically complex treatments, such as procreating for the purpose of providing treatment to the already born, but seriously ill children, must be considered by a special ethical board that would exist outside the central ethical board. According to the LBAF, decisions regarding PGD procedures rest with the Department of Biomedicine. The Department renders final decisions based on the opinion of a multidisciplinary committee for diagnostics, established in accordance with the law regulating prevention and diagnosis of genetic diseases, genetically conditioned disorders and rare diseases. The law is currently silent 


\section{4 \begin{tabular}{l|l} 
Medicine, LAW \& SOCIETY \\
S. O. Samardžić: \\
Saviour Siblings - Current Overview, Dilemmas and Possible Solutions?
\end{tabular}}

on, and so does not regulate, either the composition of this committee or the ground rules for its decision-making process. Although the PGD procedure for creating savior siblings is not currently permitted under the Serbian law, we believe that, should this procedure be allowed in the future, it would be necessary to form a committee separate from that of the Department of Biomedicine because the existence of only this body would not be sufficient, having in mind the wide range of different activities for which this body is responsible. We envison that such a committee would have precisely defined ompetences. The committee would make decisions on these sensitive procedures in addition to providing all the relevant information to future parents. In addition, it would provide an additional level of supervision and would serve as a voice of reason to parents when deciding on such sensitive matters. At the same time, when making final decisions, this committee would have to take into consideration the best interests of a wider group of people and not only the interests of an unborn child.

As stated by Taylor Sands, it is necessary to consider the following:

- interests of parents to protect and assist their existing child;

- interests of a sick child;

- interests of other siblings that would be affected by this decision;

- collective interest of the family as a whole (Taylor Sands, 2013: 136).

In addition, this committee would have to take into consideration the circumstances surrounding the family seeking medical treatment as well as the seriousness of the child's illness, the odds of a positive outcome of the treatment, as well as the consequences of a failed treatment (Taylor Sands, 2013: 136).

In the end, we believe the approach which is taken in the UK regarding saviour siblings is quite acceptable. In the UK, there is a presumption in favour of a treatment unless there is a risk of significant harm for children to be born.

Bearing in mind that this procedure does not have any impact on the physical health of the child to be born, the theoretical issues concerning both the ethical nature of such procedures and the highly speculative, possible psychological impact on the development of the personality of the child being born, seem to be quite insignificant when juxtaposed with the possibility of saving a child's life. The prohibition of such a treatment is not sufficiently justified, because in other cases, including natural conception, the motives for the birth of a child are not known. They can be much more problematic and of bigger 


\section{MEDICINE, LAW \& SOCIETY \\ S. O. Samardžić: \\ Saviour Siblings - Current Overview, Dilemmas and Possible Solutions?}

direct influence on children and their mental health. It seems beyond reasonable question that the benefits to be gained through a safe procedure which aims to save the life or health of a child should always far outweight the much less significant, and speculative/doubtful risk of adverse repercussions on the child's psychological health, which, should they actually occur, can in most cases be overcome by adequate parental skills and a well-thought out approach. Moreover, with an appropriate attitude to the children born in this process, an altruistic feeling can be developed that they have done one great thing so rare today - they helped someone. After all, "you have got to have a very powerful reason to resist the means by which [a child's] life can be saved". ${ }^{25}$

\section{Legislation, cases}

Belgian Law of 6/7/07 concerning medically assisted procreation and the use of supernumerary embryo and gametes (Moniteur Belgique du 17/07/2007) - article 68. Retrieved: https://www.zol.be/sites/default/files/deelsites/fertiliteitscentrum/wetgeving/wet_medisch begeleide_voortplanting.pdf (May 25, 2019).

Greek Law No. 3305 (Government Gazette A17 27.1.2005), Applying Medical Assisted

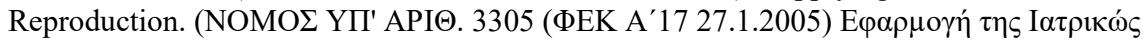

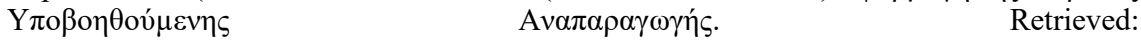
http://www.nurs.uoa.gr/fileadmin/nurs.uoa.gr/uploads/Nomothesia_Nosilefton/Nomoi/No mos_3305_FEK_A_172005.pdf(May 25, 2019).

Norwegian Law Ot.prp. nr. 26 (2006-2007), Om lov om endringer i bioteknologiloven (preimplantasjonsdiagnostikk og forskning på overtallige befruktede egg). Retrieved: https://www.regjeringen.no/no/dokumenter/otprp-nr-26-2006-2007-/id446580/sec4, (May $25,2019)$.

Portuguese Law no. 32/2006 of the Parliament, Lei n. 32/2006. de 26 de Julho. Procriação medicamente assistida. $\quad$ Retrieved: https://dre.pt/pesquisa//search/539239/details/maximized (May 25, 2019).

Serbian Law on Bio-medically Assisted Fertilisation, Official Journal of Republic of Serbia, no. 40/2017 \& 113/2017 - other law. Retrieved: http://www.pravno-informacionisistem.rs/S1GlasnikPortal/eli/rep/sgrs/skupstina/zakon/2017/40/1/reg (May 25, 2019).

Serbian Law on Transplantation of Cells and Tissue, Official Journal of Republic of Serbia, no $72 / 2009$.

Retrieved:

http://www.pravno-informacionisistem.rs/S1GlasnikPortal/reg/viewAct/25ef928b-febc-43e7-afbe-2950e3e07443, (May 25, 2019).

Spanish Law on Human Reproduction, LEY 14/2006, de 26 de mayo, sobre técnicas de reproducción humana asistida, Boletín Oficial del Estado, Número: 126, 27/05/2006, Disposición $\quad \mathrm{n}^{\mathrm{o}}$ 9292, Páginas: 19947-19956. Retrieved: http://sid.usal.es/leyes/discapacidad/9282/3-1- 2/ley-14-2006-de-26-de-mayo-sobretecnicas-de-reproduccion-humana-asistida.aspx (May 25, 2019).

Spanish Law on Human Reproduction, LEY 14/2006, de 26 de mayo, sobre técnicas de reproducción humana asistida, Boletín Oficial del Estado, Número: 126, 27/05/2006, Disposición n. 9292, Páginas: 19947-19956. Retrieved:

\footnotetext{
${ }^{25}$ Glover J. Quoted in: BBC News (online), Doctor plans "designer baby" clinic, 11 December 2001, http://news.bbc.co.uk/1/hi/health/1702854.stm, 15.5.2019.
} 
http://sid.usal.es/leyes/discapacidad/9282/3-1-

2/ley-14-2006-de-26-de-mayo-sobretecnicas-de-reproduccion-humana-asistida.aspx (May 25, 2019).

Swedish Genetic Integrity Act (2006:351). Retrieved: http:/www.smer.se/news/the-geneticintegrity-act-2006351/ (May 25, 2019).

\section{References}

Allensworth, W. (1972) Medical Jurisprudence - Parental Consent to an Operation - Parents May Authorize a Kidney Transplant from One Child to Her Identical Twin - Hart v. Brown, Texas Tech Law Review, 4(1), pp. 244-248.

Council of Europe (2015) Background document on preimplantation and prenatal genetic testing, Clinical Situation, Legal situation, available at: https://rm.coe.int/inf-2015-6-dpi-dpne/168078bad2 (May 25, 2019).

Delany, L. (1993) Law and the Altruistic Child in Medicine, In: Children \& the Law (A Series of Conference Papers presented at De Montfort University) (Leicester), pp. 39-42.

Draškić, M. (2013) Rights of Patients in Serbia: Old wine in a new bottle?, In: Perspectives of Implementation of European Standards in Serbian Legal System, Vol. 3 (Belgrade: Faculty of Law University of Belgrade, Publishing and Information Center), pp. 28-41.

Duke, K. (2006) Belgian loophole allows Swiss parents a 'saviour' baby, The Lancet, 368(9533), pp. 355-356, doi: 10.1016/S0140-6736(06)69089-2.

Ethics Committee of the Human Fertilisation and Embryology Authority (2001) Ethical issues in the creation and selection of preimplantation embryos to produce tissue donors (London), November 22, 2001, section 3.14, available at: http://hfeaarchive.uksouth.cloudapp.azure.com/www.hfea.gov.uk/docs/ELC_5 july03.pdf (December 23, 2017).

Freeman, M.D.A. (1983) The Rights and Wrongs of Children (London - Dover: Frances Pinter Publishers).

Gavaghan, C. (2007) Defending the Genetic Supermarket: Law and Ethics of Selecting the Next Generation (Routledge-Cavendish, Francis Taylor).

Gavaghan C. (2015) Saviour siblings: no avoiding the hard questions, Journal of Medical Ethics, 41(12), pp. 931-932, doi: 10.1136/medethics-2014-102605.

Glover J. Quoted in: BBC News (online) (2001) Doctor plans "designer baby" clinic, 11 December 2001, available at: http://news.bbc.co.uk/1/hi/health/1702854.stm (May 15, 2019).

Harris, J. (2000) The Welfare of the Child, Health Care Analysis, 8(1), pp. 27-34.

Hendrickson, M. (2017) 17 years later, Nash family opens up about controversial decision to save dying daughter, 14.11.2017, available at:_https://www.thedenverchannel.com/news/localnews/17-years-later-nash-family-opens-up-about-controversial-decision-to-save-dyingdaughter_(May 25, 2019).

Hudson, F (2002) Parents' plea on baby plan, Herald Sun, 17.4.2002, taken from: M. Spriggs, J. Savulescu (2002).

Jackson, E (2015) A response to Saviour Siblings: A Relational Approach to the Welfare of the Child in Selective Reproduction, Journal of Medical Ethics, 41(12), pp. 929-930, doi: 10.1136/medethics-2014-102606.

King, D. (2003) "Commentary: why it is wrong to select embryos to be tissue donors", 20.6.2003, available at: http://www.hgalert.org/topics/geneticSelection/pgdcommentary.html (May $25,2019)$.

Kraljić, S (2015) "Nadomestno materinstvo in varstvo otrokovih koristi Komentar sodbe ESČP v zadevi Paradiso in Campanelli proti Italiji”, LeXonomica, 7(1), pp. 77-83. 


\section{MEDICINE, LAW \& SOCIETY \\ S. O. Samardžić: \\ Saviour Siblings - Current Overview, Dilemmas and Possible Solutions?}

Radio Television of Serbia (2011) Evropski dan retkih bolesti, 28.2.2011, available at: http://www.rts.rs/page/stories/sr/story/125/Dru\%C5\%A1tvo/850604_(May 25, 2019).

Robertson, J.A, Kahn, J.P. \& Wagner, J.E (2002) Conception to obtain hematopoietic stem cells, Hastings Center Report, 32(3).

Robertson, J.A (2003) Extending preimplantation genetic diagnosis: medical and non-medical uses, Journal of Medical Ethics, 29(4), pp. 213-216, doi: 10.1136/jme.29.4.213.

Science and Technology Committee (2004-05) Human Reproductive Technologies and the Law: Fifth Report of Session, 1, $\$ 125, \quad$ available at: https://publications.parliament.uk/pa/cm200405/cmselect/cmsctech/7/7i.pdf (October 9, 2019).

Sheldon, S. \& Wilkinson, S. (2001) Termination of pregnancy for reason of fetal disability: are there grounds for a special exception in law?, Medical Law Review, 9(2), pp. 85-109.

Sheldon, S. \& Wilkinson, S. (2004) Should selecting saviour siblings be banned?, Journal of Medical Ethics, 30(6), pp. 533-537, doi: 10.1136/jme.2003.004150.

Spriggs, M. \& Savulescu, J (2002) Saviour Siblings, Journal of Medical Ethics, 28(5), p. 289, doi: 10.1136/jme.28.5.289.

Taylor Sands, M. (2013) Saviour Siblings - A Relational Approach to the Welfare of the Child in Selective Reproduction (New York: Routledge).

Taylor Sands, M. (2015) Saviour Siblings: reply to critics, Journal of Medical Ethics, 41(12), pp. 933-934, doi: 10.1136/medethics-2014-102607.

Wilkinson, S. (2010) Choosing Tomorrow's Children (Oxford: Oxford University Press).

Yu, Y., Wu, J., Fan, Y., Lv, Z., Guo, X. et. al. (2009) Evaluation of blastomere biopsy using a mouse model indicates the potential high risk of neurodegenerative disorders in the offspring, Molecular \& Cellular Proteomics, 8(7), pp. 1490-1500, doi: 10.1074/mcp.M800273-MCP200.

Zergollern, Lj. (1980) Book Preface, In: Rorvik D., In his Image: The Cloning of a Man (Zagreb: Prosvjeta). 
108 Medicine, LAW \& SOCIETY 